\title{
Turbidimetric Perikinetics Behaviour of Afzelia Bella Seed Biomass for Coag-Flocculation Treatment of Brewery Effluent
}

\author{
Menkiti Matthew.C. (Corresponding author) \\ Department of Chemical Engineering,Nnamdi Azikiwe University \\ PMB 5025, Awka, Nigeria \\ Tel: 234-803-744-1882 E-mail: cmenkiti@yahoo.com
}

\author{
Mbah Gordian.O. \\ Department of Chemical Engineering, Enugu State University of Science and Technology \\ PMB 01660, Enugu, Nigeria \\ Onukwuli Okechukwu.D. \\ Department of Chemical Engineering,Nnamdi Azikiwe University \\ PMB 5025, Awka, Nigeria
}

Received: July 18, 2011

Accepted: August 10, $2011 \quad$ Published: December 1, 2011

doi:10.5539/ijc.v3n4p104

URL: http://dx.doi.org/10.5539/ijc.v3n4p104

\begin{abstract}
This current article investigates at room temperature the coag -flocculation behavior of Afzelia bella seed biomass in $\mathrm{pH}$ varying brewery effluent (BRE) with respect to kinetics and efficiency. The study employed standard bench scale jar test while Afzelia bella coag-flocculant (ABC) production was based on procedure reported by Ghebremichael. Kinetics data generated were confronted with specified models for the evaluation of functional parameters such as reaction order, rate constant, period etc. The major kinetic results recorded are 2 , $8.0 \times 10^{-5} \mathrm{l} / \mathrm{mg} . \mathrm{min}$, and 2.4921 minutes for reaction order, rate constant and period, respectively. Maximum $96.1348 \%$ efficiency was recorded at $\mathrm{pH} 4,100 \mathrm{mg} / \mathrm{l}$ and 30 minutes. The results establish at pilot scale and conditions of the experiment the effectiveness of $\mathrm{ABC}$ in the treatment of brewery waste water.
\end{abstract}

Keywords: Afzelia bella, Brewery effluent, Coag-flocculation, Perikinetics, Turbidimetry

\section{Introduction}

The desire to conserve and protect the aqua system is a global one. This becomes imperative following the limited availability of usable water to a significant number of human population. The drive to tackle this challenge is faced with major problem of inadequate water treatment system at primary level. The consequence is the inability to remove to a tolerable level, the turbidity load from such raw water in order to produce usable water that is pure enough for its intended use (Ani et al., 2011). Among the raw water is brewery effluent (BRE) obtained from exit effluent of a brewery.

$\mathrm{BRE}$ is recognized as a significant environmental problem because of considerable organic and inorganic load created by brewing process (Menkiti, 2010; Menkiti \& Onukwuli, 2010). Depending on the process routes, the quality and composition of BRE fluctuate significantly. The organic components of BRE are generally biodegradable, since these mainly consist of sugars, soluble starch, ethanol, volatile fatty acids and solids which are mainly spent grains, yeast and trub (Orhue et al., 2005; Driessen \& Vereijeken, 2003). According to World Bank report, untreated BRE typically contains suspended solids (100 - $1500 \mathrm{mg} / \mathrm{l})$, chemical oxygen demand (300 - $800 \mathrm{mg} / \mathrm{l})$, nitrogen(30 - $100 \mathrm{mg} / \mathrm{l})$ and phosphorus(10 - $30 \mathrm{mg} / \mathrm{l})$ (Orhue et al., 2003). To make the BRE environment friendly, a core treatment procedure such as coag-flocculation is a first step.

Coag-flocculation is the process of adding substance to waste effluent (e.g BRE) to make the suspended and dissolved particles (SDP) to bind together (coagulation) and subsequently aggregate into visible flocs 
(flocculation) that settle out of the water (Menkiti \& Onukwuli, 2011a; Menkiti \& Onukwuli, 2011b; Menkiti \& Onukwuli, 2011c; Oladoja \& Aliu, 2009). Inorganic substances such as alum and polyaluminium chloride (PACl) have had established application in the removal of effluent SDP because they are easy to handle and widely available. However, its applications have raised environmental and public health concerns. It is known that alzheimer's disease is associated with significant intake of alum (Chatterjee et al., 2009; Driscoll \& Letterman, 1995; Mclachan, 1995). The harmful effects of these conventional coagulants are the motivation for the search and the use of natural products such as Afzelia bella coag-flocculant as alternative (Menkiti et al., 2010; Menkiti et al., 2008; Menkiti et al., 2009).

Afzelia bella is a leguminous plant, rich in protein, fat, and starch. It is native to tropical climate such as Eastern Nigeria. Afzelia bella is an edible, non-toxic and biodegradable substance. Previous results had indicated the effective application of Afzelia bella as coag-flocculant in coal washery effluent treatment (Menkiti, 2010; Menkiti \& Onukwuli, 2011c).

In this present study, the coag-flocculation kinetics response to $\mathrm{pH}$ variation with respect to BRE treatment is investigated. The efficiency of the treatment process as a function of time, $\mathrm{pH}$, and dosage was also studied. The situations in Nigeria are typical of water system in developing countries and results of this study can be extended to a number of similar situations for the upliftment of our environment.

\section{Theory}

\subsection{Coag-flocculation kinetic}

For a coag-flocculating phase, the rate of successful collision between particles of sizes $\mathrm{i}$ and $\mathrm{j}$ to form particle of size k is (Thomas et al., 1999; Swift \& Friedlander, 1964; Jin, 2005; Hunter, 1993):

$$
\frac{d n_{k}}{d t}=\frac{1}{2} \sum_{i+j=k} \beta_{B R}(i, j) n_{i} n_{j}-\sum_{i=1}^{\alpha} \beta_{B R}(i, k) n_{i} n_{k}
$$

Where $\beta_{\mathrm{BR}(\mathrm{i}, \mathrm{j})}$ is Brownian aggregation factor for flocculation transport mechanism, $\mathrm{n}_{\mathrm{i}} \mathrm{n}_{\mathrm{j}}$ is particle aggregation concentration for particles of size $\mathrm{i}$ and $\mathrm{j}$, respectively. It has been established that (Jin, 2005; Hunter, 1993; Fridkhsberg, 1984):

$$
\begin{gathered}
\beta_{B R}=\frac{8}{3} \varepsilon_{p} \frac{K_{B} T}{\eta} \\
K_{R}=8 \pi a D^{\prime}
\end{gathered}
$$

Where $K_{R}$ is the Von Smoluchowski rate constant for rapid coagulation. $K_{B}, T$ and $\eta$ are Boltzmann constant, temperature and viscosity, respectively. $\varepsilon_{\mathrm{p}}$ is collision efficiency factor, $\mathrm{D}^{\prime}$ is the diffusion coefficient and a is particle radius.

Equations 2 and 3 can be transformed to

$$
\frac{1}{2} \beta_{B R}=K_{m}
$$

Where $\mathrm{K}_{\mathrm{m}}$ is defined as Menkonu coag-flocculation rate constant accounting for Brownian coag-flocculation transport of destabilized particles at $\alpha^{\text {th }}$ order. It can also be shown that coag-flocculation is governed by (Smoluchowski, 1917; Van Zanten \& Elimelech, 1992; Menkiti \& Onukwuli, 2010; Menkiti \& Onukwuli, 2011a):

$$
\begin{gathered}
-\frac{d N_{t}}{d t}=\varepsilon_{p} K_{R} N_{t}^{\alpha} \\
\text { Where } \varepsilon_{p} K_{R}=0.5 \beta_{B R} \\
\text { Thus }-\frac{d N_{t}}{d t}=K_{m} N_{t}^{\alpha}
\end{gathered}
$$

$\mathrm{N}_{\mathrm{t}}$ is the concentration of SDP at time, $\mathrm{t}$. 
Empirical evidence shows that in real practice, $1<\alpha<2$ (WST, 2005; Menkiti et al., 2008; Menkiti et al., 2009; Menkiti, 2010; Menkiti et al., 2010). Graphical representation of linear form of equation (7) at $\alpha=2$ provides for $\mathrm{K}_{\mathrm{m}}$ from the slope of linear equation8 below:

$$
\frac{1}{N}=K_{m} t+\frac{1}{N_{0}}
$$

where $\mathrm{N}_{0}$ is the initial $\mathrm{N}_{\mathrm{t}}$ at time $=0 ; \mathrm{N}$ is $\mathrm{N}_{\mathrm{t}}$ at upper time limit $>0$

Equation 8 can be solved to obtain coag-flocculation period, $\tau_{1 / 2}$ :

$$
\tau_{1 / 2}=\left(0.5 N_{0} K_{m}\right)^{-1}
$$

Equation 1, solved exactly, results in generic expression for microscopic aggregation:

$$
\frac{N_{m(t)}}{N_{0}}=\frac{\left[1 / \tau_{1 / 2}\right]^{m-1}}{\left[1+\frac{t}{\tau_{1 / 2}}\right]^{m+1}}
$$

$\mathrm{M}=1$ (monomers), $\mathrm{m}=2$ (dimmers), $\mathrm{m}=3$ (trimmers)

Efficiency of coag-flocculation is expressed as:

$$
E(\%)=\left[\frac{N_{0}-N_{t}}{N_{0}}\right] 100
$$

\section{Materials and methods}

\subsection{Materials collection, preparation and characterization}

\subsubsection{Brewery effluent (BRE)}

The effluent was taken from a major brewery located in Enugu, Enugu State, Nigeria. The characterization of the effluent presented in table 1 were determined based on standard method (Clesceri et al., 1999).

\subsubsection{Afzelia bella seed sample}

Afzelia bella seed samples (precursor to ABC) were sourced from Nsugbe, Anambra State, Nigeria. ABC was prepared according to procedure reported by Ghebremichael (2004). The characteristics of the sample on the bases of AOAC (1993) standard method are presented in table 2.

\subsection{Coag-flocculation Experiments}

Experiments were conducted using conventional jar test apparatus. Appropriate dosage of $\mathrm{ABC}$ in the range 100 - $500 \mathrm{mg} / \mathrm{l}$ was added directly to $200 \mathrm{ml}$ of BRE. The suspension, tuned to $\mathrm{pH}$ range $2-10$ by application of $\mathrm{H}_{2} \mathrm{SO}_{4} / \mathrm{NaOH}$ was subjected to 2 minutes of rapid mixing $(250 \mathrm{rpm}), 20$ minutes of slow mixing $(20 \mathrm{rpm})$ and followed by 30 minutes of settling. During settling, samples were withdrawn from $2 \mathrm{~cm}$ depth and changes in SDP (in $\mathrm{mg} / \mathrm{l}$ ) measured for kinetic analysis. The aggregation kinetics readings at room temperature were monitored and collected at 3, 5, 10, 15, 20, 25 and 30 minutes. The data were subsequently fitted in appropriate kinetic models.

\section{Results and discussion}

\subsection{Process Kinetic Parameters}

Kinetic parameters associated with coag-flocculation process are important functional quantities that determine the physical and theoretical behavior of the system. The parameters have direct bearing on the design, fabrication and practical implementation of the process. Such important parameters are presented in tables 3-7 for the removal of SDP from BRE by $100,200,300,400,500 \mathrm{mg} / \mathrm{l} \mathrm{ABC}$. The experiments were carried out at BRE pH of $2,4,6,8,10$.

Linear regression coefficient $\left(\mathrm{R}^{2}\right)$ was employed in evaluation of the level of accuracy of fit of the experimental data on the principal model expressed as equation 8. Tables 3-7 indicate that data (with majority of $R^{2}>0.9$ ) were significantly described by the linearised form of equation 7 expressed as equation 8 . 
Reaction rate constant, denoted as $\mathrm{K}_{\mathrm{m}}$, is determined from slope of equation 8. From equation 7 , it can be deduced that the rate of reaction is directly proportional to the magnitude of $\mathrm{K}_{\mathrm{m}}$. Hence, higher $\mathrm{K}_{\mathrm{m}}$ translates to higher rate of coag-flocculation. $K_{m}$ is evaluated by fitting the experimental data on the plot of $(1 / \mathrm{N})$ or $(1 / \mathrm{SDP})$ against time as can be deduced from equation 8. Representative results for the various dosages and $\mathrm{pH}$ as displayed in tables 3-7 are graphically depicted in figure 1. It should be noted that the graphical trends (not shown) for the various dosages and $\mathrm{pH}$ are identical. $\mathrm{K}_{\mathrm{m}}=\left(0.5 \beta_{\mathrm{BR}}\right)$ expressed as equation 4 is displayed in tables 3-7. The maximum and minimum values of $\mathrm{K}_{\mathrm{m}}$ are $8.0 \times 10^{-5}\left(\mathrm{pH} 4\right.$ and $100 \mathrm{mg} / \mathrm{l}$ ) and $5.0 \times 10^{-7} \mathrm{l} / \mathrm{mg} \cdot \mathrm{min}$ (pH 10 and 100,300, $400 \mathrm{mg} / \mathrm{l})$, respectively. Apparently, the best performance was achieved at acidic medium of $\mathrm{pH}$ 2. This could be attributed to a higher degree of protonation of amine groups present in the $\mathrm{ABC}$ biomass. It is known that protonation by dissociated $\mathrm{H}_{2} \mathrm{SO}_{4}$ enhances coag-flocculation rate (Gibbs et al., 2003). Conversely, performance at alkaline medium $(\mathrm{pH} 8-10)$ is relatively lower. This can be attributed to electrostatic charge imbalance in the coag-flocculating phase due to the inability of alkaline cation to adequately favour delamination of the coag-flocculating phase. The consequence is the prevalence of inaccessible surface (Chatterjee et al., 2009; Assad et al., 2007).

Two vital quantities affecting coag-flocculation are $\varepsilon_{p}$ and $K_{R}$. $K_{R}$ links the coag-flocculating phase with temperature and viscosity of the fluid. Following monotonic temperature and viscosity ranges, minimal variation in the values of $K_{R}$ was recorded as displayed on tables 3-7. At approximately constant $K_{R}, \varepsilon_{p}$ relates directly to $2 \mathrm{~K}_{\mathrm{m}}=\beta_{\mathrm{BR}}$ (equation 4). Thus, high $\varepsilon_{\mathrm{p}}$ results in high kinetic energy providing particle momentum to ensure the overcoming of opposing electrostatic forces by the aggregating particles. It should be observed that high repulsive forces means high zeta potential, which in this present communication is relatively low and high at $\mathrm{pH}$ 2 and $\mathrm{pH} 10$, respectively. It has been reported that $\tau_{1 / 2}, \varepsilon_{\mathrm{p}}$ and $\mathrm{K}_{\mathrm{R}}$ are understood to be effectiveness factor, postulated to be accounting for the coag-flocculation efficiency before flocculation commences (Menkiti \& Onukwuli, 2011a; Menkiti \& Onukwuli, 2011c). The coag-flocculation period, $\tau_{1 / 2}$, evaluated from equation 9 , is a pointer to speed of the aggregation of the system. Low period indicates fast rate of aggregation. Practically, it is aimed to keep the $\tau_{1 / 2}$ as low as possible. From equation 9, it can be inferred that $\tau_{1 / 2}$ is a function of rate constant and initial SDP concentration, mathematically, expressed as $\tau_{1 / 2}=f n\left(N_{0}, K_{m}\right)$. The implication from equation 9 , is that, the higher the $\mathrm{N}_{0}$, the lesser the $\tau_{1 / 2}$. This accounts for high settling rate associated with waters of high initial turbidity. Generally, the observed discrepancies among the functional kinetic parameters are due to unattainable assumption that mixing of BRE particles and ABC throughout the dispersion is $100 \%$ efficient before aggregation sets in (Menkiti \& Onukwuli, 2010; Holthof et al., 1996; Holthof et al., 1997; Yates et al., 2001). Second account is the interplay between Vander Wall's forces and the hydrodynamic interactions which typically alters the theoretically predicted values by factors of \pm 2 .

\subsection{Temporal Evolution of Cluster Size Distribution}

The temporal evolution of cluster size distribution graphically depicts particle distribution as a function of time at a microscopic level. By substituting $\tau_{1 / 2}$ from equation 9 into 10, the particle aggregation at microscopic levels can be predicted graphically by the interaction of monomers $(\mathrm{m}=1)$; dimmers $(\mathrm{m}=2)$ and trimmers $(\mathrm{m}=3)$. Representatives' results are shown in figures 2 and 3. The apparent variation in the nature of the curves in response to two different $\tau_{1 / 2}$ of 2.4921 and 398.7491 minutes are demonstrated as cases I and II, respectively.

Case I: This is demonstrated graphically in figure 2. In this case, the monomers and particles can be seen to decrease more. This case demonstrates moderately hyper slope with time. This distribution profile is associated with above moderate rapid destabilization of charged particles. The physical implication of this profile is product of low $\tau_{1 / 2}$ that runs into minutes rather than subminutes. Elsewhere, $\tau_{1 / 2}$ of less than 1.5 seconds had been reported by Hunter (1993). The $\tau_{1 / 2}$ evaluated for figure 2 is a pointer to the prevalence of middle level zeta potential that results in moderate sweeping away of SDP under gravity from the bulk fluid phase.

Case II: Figure 3 depicts particle distribution with strong inertia against aggregation. This is clearly demonstrated by high value of $\tau_{1 / 2}$ recorded at 398.7491 minutes. The figure represents a case in which the values of triplets and particles sum are close such that their variation with time is insignificant. Similar trend is observed with respect to dimmers and monomers. Figure 2 showcases a wide margin of difference in concentrations of SDP between the pair of (trimmers and particle sum) and (dimmers and monomers). The margin exists as a result of high shear force and resistance to collision. This is an indication of high zeta potential associated with the BRE treatment process.

\subsection{Temporal \% Removal Efficiency For Varying $p H$ and ABC dosages}

The process efficiency graphically presented in figures 4-8 are obtained upon evaluation of equation 11 . The figures depict the variation of efficiency, $\mathrm{E}(\%)$ as a function of time and $\mathrm{pH}$ for various $\mathrm{ABC}$ dosages of 100 , 
$200,300,400$ and $500 \mathrm{mg} / \mathrm{l}$. It is apparent that the trends for all the cases studied are almost identical but with different percentages of efficiency achieved for a particular $\mathrm{pH}$ and dosage. The coag-flocculation efficiency at early time was generally between $60-70 \%$ at pH 2 and 4 for all cases of dosages. However, exceptions were recorded for $\mathrm{pH} 8$ and 10 where $\mathrm{E}$ (\%) of less than $60 \%$ is also recorded. Practically, more than $80 \%$ efficiency was achieved at 30 minutes for $\mathrm{pH} 2$ and 4 with respect to all dosages considered. The implication is that $>80 \%$ of initial SDP load of $10031.87 \mathrm{mg} / \mathrm{l}$ was removed at 30 minutes of treatment. Recall that it had earlier been adduced that satisfactory performance achieved at $\mathrm{pH} 2$ and 4 is because the amine group of $\mathrm{ABC}$ was protonated by $\mathrm{H}^{+}$produced from the dissociation of $\mathrm{H}_{2} \mathrm{SO}_{4}$. The best performance was achieved with $100 \mathrm{mg} / \mathrm{l}$ $\mathrm{ABC}$, though other dosages recoded satisfactory results at $\mathrm{pH} 2$ and 4. Mechanism of coag-flocculation has been postulated to have effects on the influence of dosage on the aggregation. Effective treatment could be achieved with relatively lower doses of $\mathrm{ABC}$ especially when complete charge neutralization is not required and process guided by combine impacts of electrostatic patch and bridging mechanism (Chatterjee et al., 2009). Following the performance of $100 \mathrm{mg} / \mathrm{l} \mathrm{ABC}$, it is adopted for comparison with conventional alum in figure 9.

\subsection{Comparative Coag-flocculation Performance Of ABC and Alum}

The comparative performance between $\mathrm{ABC}$ and alum at the same experimental conditions is presented in figure 9 at $100 \mathrm{mg} / 1$ and $\mathrm{PH} \mathrm{2,4,6,8,10.} \mathrm{Like} \mathrm{previously} \mathrm{inferred,} \mathrm{at} \mathrm{the} \mathrm{conditions} \mathrm{of} \mathrm{the} \mathrm{experiment,} \mathrm{the} \mathrm{highest} \mathrm{and}$ least $\mathrm{E}(\%)$ were achieved at $\mathrm{pH} 4$ and 10, respectively. It should be noted that $\mathrm{ABC}$ performed better than alum at only $\mathrm{pH} 2$ and 4 while alum did better at $\mathrm{pH} 6-10$. The reason for the variation in performance of $\mathrm{ABC}$ as $\mathrm{pH}$ varied had earlier been explained in this communication. At pH 2 and 4, the E (\%) posted are 94.2373 and 96.1348, respectively. The least E (\%) of 62.9879 is recorded for $\mathrm{pH} 10$ at 30 minutes of treatment. Similar results (not shown) were obtained for 200,300, 400, and $500 \mathrm{mg} / 1 \mathrm{ABC}$ dosages. The fact is that $\mathrm{ABC}$ at $\mathrm{pH} 2$ and 4 compares favourably with alum, with advantage of being eco-friendly.

\section{Conclusion}

The application at a pilot scale of $\mathrm{ABC}$ as effective coag-flocculant in the treatment of high organic load BRE has been established, with respect to conditions of the experiment. This presents novelty in this work. The level of SDP removal achieved at 30 minutes follows perikinetics. At the conditions of the experiment, the system operates best at $100 \mathrm{mg} / 1, \mathrm{pH} 4$ and $96.1348 \%$ efficiency.

\section{References}

Ani, J.U., Menkiti, M.C., \& Onukwuli, O.D. (2011). Coagulation-Flocculation Performance of Snail Shell Biomass for Waste Water Purification. New York Science Journal, 4 (2), 81-90.

AOAC. (1993). Official methods of Analysis. Association of official analytical chemist. (14th ed). USA.

Assad, E., Azzouz, A., Nistro, D., Ursu, A.V., Sajin, T., Miron, D.N., Monette, F., Niquette, P., \& Hausler, R. (2007). Metal removal through synergic coagulation-flocculation using an optimized chitosan-montmorillonite system. Applied Clay Science, 37, 258-274. http://dx.doi.org/10.1016/j.clay.2007.02.007

Chatterjee, T., Chatterjee, S., \& Woo, S.H. (2009). Enhanced coagulation of bentonite particles in water by modified chitosan biopolymer. Chemical Engineering Journal, 148, 414-419. http://dx.doi.org/10.1016/j.cej.2008.09.016

Clesceri, L.S., Greenberg, A.E., \& Eaton, A.D. (1999). Standard methods for the examinatin of water and waste water. (20th ed). USA: APHA.

Driessen, W., \& Vereijken, T. (2003). Recent development in biological treatment of brewery effluent. Inst. and Guild of Brew. Africa Sect. -Proc. 9th Brewing Convention, Zambia. 165-171.

Driscoll, C.T., \& Letterman, E.R. (1995). Factors regulating residual aluminium concentration in treated waters. Environmetrics, 6, 233-275. http://dx.doi.org/10.1002/env.3170060306

Fridkhsberg, D.A. (1984). A course in colloid chemistry. Moscow, Russia: Mir Publishers.

Ghebremichael, K. (2004). Moringa seed and pumice as alternative natural materials for drinking water treatment. TRITAL-LWR PHD 1013 Ph.D Thesis, KTH Land and Water Resources Engineering.

Gibbs, G., Tobin, J.M., \& Guibal E. (2003). Sorption of acid green 25 on chitosan: Influence of experimental parameters on uptake kinetics and sorption isotherms. J. Appl. Polym. Sci., 90, 1073-1080. http://dx.doi.org/10.1002/app.12761 
Holthof, H., Egelhaaf, S.U., Schurtenberger, P., \& Sticher, H. (1996). Coagulation rate measurement of colloidal particles by simultaneous static and dynamic light scattering. Langmuir, 12, 5541. http://dx.doi.org/10.1021/la960326e

Holthof, H., Schmitt, A., Fernandez-Barbero, M., Borkovec, M., Cabrerizo-Vilehez, P., Schutengberger, P., \& Hidalgo-Alvarez, R. (1997). Coagulation rate constants for colloidal particles: Comparison of single and multi angle light scattering techniques. Journal of colloidal and interface science, 192, 463-470.

Hunter, R.J. (1993). Introduction to Modern Colloid Science. (4th ed.). New York: University press.

Jin, Y. (2005). Use of high resolution photographic technique for studying coagulation/flocculation in water treatment. M.Sc Thesis. University of Saskatchewan, Saskatoon, Canada.

McLachian, D.R.C. (1995). Aluminium and the risk for Alzheimer's disease. Environmetrics, 6, 233-275.

Menkiti, M.C., \& Onukwuli, O.D. (2010). Coag-flocculation studies of Moringa oleifera coagulant (MOC) in brewery effluent: Nephelometric approach. Journal of American Science, 6(12), 788-806.

Menkiti, M.C., Nnaji, P.C., Nwoye, C.I., \& Onukwuli, O.D. (2010). Coag-flocculation kinetics and functional parameters response of mucuna coagulant to $\mathrm{pH}$ variation in organic rich coal effluent medium. Journal of Mineral and Material Characterisation and Engineering, 9(2), 89-103.

Menkiti, M.C. (2010). Sequential treatments coal washery and brewery effluents by biocoag-flocculation and activated carbon adsorption. Ph.D Thesis. Department of Chemical Engineering, Nnamdi Azikiwe University, Awka, Nigeria.

Menkiti, M.C., \& Onukwuli, O.D. (2011a). Single and multi angle nephelometric approach to the study of coag-flocculation of coal effluent medium using Brachystegia eurycoma coagulant. World Journal of Engineering, 8(1), 61-76. http://dx.doi.org/10.1260/1708-5284.8.1.61

Menkiti, M.C., \& Onukwuli, O.D. (2011c). Coag-flocculation studies of Afzelia bella coagulant (ABC) in coal effluent using single and simulated multi angle nephelometry. Journal of Mineral and Material Characterisation and Engineering, 10(3), 279-298.

Menkiti, M.C., \& Onukwuli, O.D. (2011b). Coag-flocculation of Mucuna seed coag-flocculant (MSC) in coal washery effluent (CWE) using light scattering effects. AICHE Journal, 57(5). http://dx.doi.org/10.1002/aic.12665

Menkiti, M.C., Igbokwe, P.K., Ugodulunwa, F.X.O., \& Onukwuli, O.D. (2008). Rapid coagulation/flocculation kinetics of coal effluent medium with high organic content using blended and unblended chitin derived coagulant (CDC). Research Journal of Applied Science, 3(4), 317-323.

Menkiti, M.C., Nnaji, P.C., \& Onukwuli, O.D. (2009). Coag-flocculation kinetics and functional parameters response of periwinkle shell coagulant (PSC) to $\mathrm{pH}$ variation in organic rich coal effluent medium. Nature and Science, 7(6), 1-8.

Oladoja, A.N., \& Aliu Y.D. (2009). Snail shell as coagulant aid in the alum precipitation of malachite green from aqua system. Journal of Hazardous Materials, 164(2-3), 1496-1502. http://dx.doi.org/10.1016/j.jhazmat.2008.09.114

Orhue, E.R., Osaigbovo, A.U., \& Vwioko D.E. (2005). Growth of maize (Zea may L) and changes in some chemical properties of an ultisol amended with brewery effluent. African Journal of Biotechnology, 4(9), 973-978.

Swift, D.L., \& Friedlander, S.K. (1964). The coagulation of hydrosol by Brownian motion and laminar shear flow. Journal of Colloids Science, 19, 621. http://dx.doi.org/10.1016/0095-8522(64)90085-6

Thomas, D.N., Judd, S.J., \& Fawcett, N. (1999). Flocculation modeling: A review. Water Resource, 33(7), 1579-1592. http://dx.doi.org/10.1016/S0043-1354(98)00392-3

Van Zanten, J.H., \& Elimelech, M. (1992). Determination of Rate constants by multiangle light scattering. Journal of colloid and interface, 154(1), 1-7. http://dx.doi.org/10.1016/0021-9797(92)90072-T

Von Smoluchowski, M. (1917). Versucheiner Mathematischen Theorie der Koagulations Kinetic Kolloider Lousungen. Z. Phys. Chem., 92, 129-168. (in German).

Water Specialist Technology (W S T). (2005). About coagulation flocculation: Information Bulletin. USA.

Yates, P., Yan, Y., Jamson, G.J., \& Biggs, S. (2001). Heteroaggregation of particle system: Aggregation Mechanisms and aggregate structure determination. 6th World Congress of Chemical Engineering, Melbourne, Australia, 23rd -27th September. 1-10. 
Table 1. Characteristics of Brewery Effluent

\begin{tabular}{|c|c|}
\hline Parameters & Values \\
\hline $\mathrm{pH}$ & 6.940 \\
\hline Turbidity (NTU) & 4269.700 \\
\hline Total hardness (mg/l) & 68.000 \\
\hline Ca hardness (mg/l) & 51.000 \\
\hline Mg hardness (mg/l) & 18.000 \\
\hline $\mathrm{Ca}^{2+}(\mathrm{mg} / \mathrm{l})$ & 20.400 \\
\hline $\mathrm{Mg}^{2+}(\mathrm{mg} / \mathrm{l})$ & 5.400 \\
\hline $\mathrm{Fe}^{2+}(\mathrm{mg} / \mathrm{l})$ & 0.180 \\
\hline $\mathrm{SO}_{4}{ }^{2-}(\mathrm{mg} / \mathrm{l})$ & 48.140 \\
\hline $\mathrm{NO}_{3}{ }^{2-}(\mathrm{mg} / \mathrm{l})$ & 0.150 \\
\hline $\mathrm{Cl}^{-}(\mathrm{mg} / \mathrm{l})$ & 18.994 \\
\hline E.cond $\left(\mu \mathrm{m} / \mathrm{m}^{2}\right)$ & 480.000 \\
\hline TDS (mg/l) & 268.810 \\
\hline $\mathrm{TSS}(\mathrm{mg} / \mathrm{l})$ & 27.301 \\
\hline T.Coliform & 13.001 \\
\hline Plate Count & 72.000 \\
\hline E-Coli & Nil \\
\hline $\mathrm{BOD}_{3}$ & 672.003 \\
\hline
\end{tabular}

Table 2. Characteristics of $\mathrm{ABC}$ precursor

\begin{tabular}{|c|c|}
\hline Parameter & Value \\
\hline Moisture content (\%) & 5.800 \\
\hline Ash content (\%) & 3.800 \\
\hline Lipid content (\%) & 10.200 \\
\hline Crude protein (\%) & 13.125 \\
\hline Carbohydrate (\%) & 60.064 \\
\hline Crude fibre (\%) & 7.011 \\
\hline
\end{tabular}

Table 3. Functional kinetic parameters of $\mathrm{ABC}$ in $\mathrm{BRE}$ at $100 \mathrm{mg} / \mathrm{l}$ dosage

\begin{tabular}{|c|c|c|c|c|c|}
\hline Parameters & $\mathrm{pH}=2$ & $\mathrm{pH}=4$ & $\mathrm{pH}=6$ & $\mathrm{pH}=8$ & $\mathrm{pH}=10$ \\
\hline$\alpha$ & 2.0000 & 2.0000 & 2.0000 & 2.0000 & 2.0000 \\
\hline $\mathrm{R}^{2}$ & 0.9138 & 0.9844 & 0.9030 & 0.9028 & 0.9019 \\
\hline$K_{m}(l / m g \cdot \min )$ & $4 \mathrm{E}-05$ & $8 \mathrm{E}-05$ & $7 E-06$ & $9 \mathrm{E}-07$ & $5 \times 10^{-7}$ \\
\hline$\beta_{B R}(l / m g \cdot \min )$ & $8 E-05$ & $1.6 \mathrm{E}-04$ & $1.4 \mathrm{E}-05$ & $1.8 \mathrm{E}-06$ & $1.0 \times 10^{-6}$ \\
\hline$K_{R}(1 / \min )$ & $9.0574 \times 10^{-12}$ & $8.9995 \times 10^{-12}$ & $7.6439 \times 10^{-12}$ & $7.4093 \times 10^{-12}$ & $7.6456 \times 10^{-12}$ \\
\hline$\varepsilon_{p}(1 / m g)$ & $8.8325 \times 10^{6}$ & $1.7778 \times 10^{7}$ & $1.8315 \times 10^{6}$ & $1.8315 \times 10^{6}$ & $1.3079 \times 10^{5}$ \\
\hline$\tau_{1 / 2}(\min )$ & 4.9843 & 2.4921 & 28.4820 & 221.5272 & 398.7491 \\
\hline$N_{0}(\mathrm{mg} / \mathrm{l})$ & 5000.0000 & 5000.0000 & 5000.0000 & 3333.3300 & 3333.3300 \\
\hline$\left(N_{P}\right)_{0}$ & $3.011 \times 10^{24}$ & $3.011 \times 10^{24}$ & $3.0110 \times 10^{24}$ & $2.0073 \times 10^{24}$ & $2.0073 \times 10^{24}$ \\
\hline
\end{tabular}


Table 4. Functional kinetic parameters of ABC in BRE at $200 \mathrm{mg} / \mathrm{l}$ dosage

\begin{tabular}{|c|c|c|c|c|c|}
\hline Parameters & $\mathrm{pH}=2$ & $\mathrm{pH}=4$ & $\mathrm{pH}=6$ & $\mathrm{pH}=8$ & $\mathrm{pH}=10$ \\
\hline$\alpha$ & 2.0000 & 2.0000 & 2.0000 & 2.0000 & 2.0000 \\
\hline $\mathrm{R}^{2}$ & 0.9861 & 0.9861 & 0.9395 & 0.9298 & 0.9316 \\
\hline$K_{m}(1 / m g \cdot \min )$ & $3 \mathrm{E}-05$ & $4 \mathrm{E}-05$ & $3 \mathrm{E}-06$ & $3 \mathrm{E}-06$ & $2 \mathrm{E}-05$ \\
\hline$\beta_{B R}(1 / m g \cdot \min )$ & $6 \mathrm{E}-05$ & $8 \mathrm{E}-05$ & $6 \mathrm{E}-06$ & $6 \mathrm{E}-06$ & $4 \mathrm{E}-06$ \\
\hline$K_{R}(1 / \min )$ & $9.0475 \times 10^{-12}$ & $1.0123 \times 10^{-11}$ & $8.1765 \times 10^{-12}$ & $9.0067 \times 10^{-12}$ & $9.1435 \times 10^{-12}$ \\
\hline$\varepsilon_{p}(1 / m g)$ & $6.6316 \times 10^{6}$ & $7.9027 \times 10^{6}$ & $7.3380 \times 10^{5}$ & $6.6616 \times 10^{5}$ & $4.3746 \times 10^{5}$ \\
\hline$\tau_{1 / 2}(\mathrm{~min})$ & 6.6458 & 4.9843 & 66.4581 & 66.4581 & 99.6872 \\
\hline$N_{0}(\mathrm{mg} / l)$ & 5000.0000 & 3333.3300 & 5000.0000 & 5000.0000 & 5000.0000 \\
\hline$\left(N_{P}\right)_{0}$ & $3.0110 \times 10^{24}$ & $2.0073 \times 10^{24}$ & $3.0110 \times 10^{24}$ & $3.0110 \times 10^{24}$ & $3.0110 \times 10^{24}$ \\
\hline
\end{tabular}

Table 5. Functional kinetic parameters of $\mathrm{ABC}$ in BRE at $300 \mathrm{mg} / \mathrm{l}$ dosage

\begin{tabular}{|c|c|c|c|c|c|}
\hline Parameters & $\mathrm{pH}=2$ & $\mathrm{pH}=4$ & $\mathrm{pH}=6$ & $\mathrm{pH}=8$ & $\mathrm{pH}=10$ \\
\hline$\alpha$ & 2.0000 & 2.0000 & 2.0000 & 2.0000 & 2.0000 \\
\hline $\mathrm{R}^{2}$ & 0.7313 & 0.9734 & 0.7009 & 0.8884 & 0.3254 \\
\hline$K_{m}(1 / m g \cdot \min )$ & $2 \mathrm{E}-05$ & $4 \mathrm{E}-05$ & $9 \mathrm{E}-07$ & $9 \mathrm{E}-06$ & $5 \times 10^{-7}$ \\
\hline$\beta_{B R}(1 / m g \cdot \min )$ & $4 \mathrm{E}-05$ & $8 \mathrm{E}-05$ & $1.8 \mathrm{E}-05$ & $1.8 \mathrm{E}-05$ & $1.0 \times 10^{-7}$ \\
\hline$K_{R}(1 / m i n)$ & $8.0599 \times 10^{-12}$ & $8.7947 \times 10^{-12}$ & $8.0628 \times 10^{-12}$ & $7.6747 \times 10^{-12}$ & $9.1175 \times 10^{-12}$ \\
\hline$\varepsilon_{p}(1 / m g)$ & $4.9628 \times 10^{6}$ & $9.0963 \times 10^{6}$ & $2.2324 \times 10^{6}$ & $2.3455 \times 10^{6}$ & $1.0967 \times 10^{4}$ \\
\hline$\tau_{1 / 2}(\mathrm{~min})$ & 9.9687 & 4.9843 & 221.5272 & 22.1527 & 398.1491 \\
\hline$N_{0}(m g / l)$ & 5000.0000 & 3333.3300 & 3333.3300 & 5000.00 & 3333.3300 \\
\hline$\left(N_{P}\right)_{0}$ & $3.0110 \times 10^{24}$ & $2.0073 \times 10^{24}$ & $2.0073 \times 10^{24}$ & $3.0110 \times 10^{24}$ & $2.0073 \times 10^{24}$ \\
\hline
\end{tabular}

Table 6. Functional kinetic parameters of $\mathrm{ABC}$ in $\mathrm{BRE}$ at $400 \mathrm{mg} / \mathrm{l}$ dosage

\begin{tabular}{|c|c|c|c|c|c|}
\hline Parameters & $\mathrm{pH}=2$ & $\mathrm{pH}=4$ & $\mathrm{pH}=6$ & $\mathrm{pH}=8$ & $\mathrm{pH}=10$ \\
\hline$\alpha$ & 2.0000 & 2.0000 & 2.0000 & 2.0000 & 2.0000 \\
\hline $\mathrm{R}^{2}$ & 0.9597 & 0.9740 & 0.9478 & 0.9301 & 0.9043 \\
\hline$K_{m}(1 / m g \cdot \min )$ & $1 \mathrm{E}-05$ & $4 \mathrm{E}-05$ & $9 \mathrm{E}-06$ & $3 \mathrm{E}-06$ & $5 \times 10^{-7}$ \\
\hline$\beta_{B R}(1 / m g \cdot \min )$ & $2 \mathrm{E}-05$ & $8 \mathrm{E}-05$ & $1.8 \mathrm{E}-04$ & $6 \mathrm{E}-06$ & $1.0 \times 10^{-7}$ \\
\hline$K_{R}(1 / m i n)$ & $7.2037 \times 10^{-12}$ & $9.2638 \times 10^{-12}$ & $8.3501 \times 10^{-12}$ & $7.5343 \times 10^{-12}$ & $8.3340 \times 10^{-12}$ \\
\hline$\varepsilon_{p}(1 / m g$ & $2.7763 \times 10^{6}$ & $8.6356 \times 10^{6}$ & $2.1554 \times 10^{7}$ & $7.9635 \times 10^{5}$ & $1.1998 \times 10^{4}$ \\
\hline$\tau_{1 / 2}(\mathrm{~min})$ & 19.9374 & 4.9843 & 221.5272 & 66.4581 & 398.1491 \\
\hline$N_{0}(m g / l)$ & 3333.3300 & 5000.0000 & 2000.0000 & 5000.00 & 3333.3300 \\
\hline$\left(N_{P}\right)_{0}$ & $2.0073 \times 10^{24}$ & $3.0110 \times 10^{24}$ & $1.2044 \times 10^{24}$ & $3.0110 \times 10^{24}$ & $2.0073 \times 10^{24}$ \\
\hline
\end{tabular}


Table 7. Functional kinetic parameters of $\mathrm{ABC}$ in BRE at $500 \mathrm{mg} / \mathrm{l}$ dosage

\begin{tabular}{|c|c|c|c|c|c|}
\hline Parameters & $\mathrm{pH}=2$ & $\mathrm{pH}=4$ & $\mathrm{pH}=6$ & $\mathrm{pH}=8$ & $\mathrm{pH}=10$ \\
\hline$\alpha$ & 2.0000 & 2.0000 & 2.0000 & 2.0000 & 2.0000 \\
\hline $\mathrm{R}^{2}$ & 0.9725 & 0.9851 & 0.9624 & 0.9456 & 0.9419 \\
\hline$K_{m}(1 / m g \cdot \min )$ & $2 \mathrm{E}-05$ & $4 \mathrm{E}-05$ & $3 \mathrm{E}-06$ & $7 \mathrm{E}-07$ & $6 \times 10^{-7}$ \\
\hline$\beta_{B R}(1 / m g \cdot \min )$ & $4 \mathrm{E}-05$ & $8 \mathrm{E}-05$ & $6 \mathrm{E}-06$ & $1.4 \mathrm{E}-06$ & $1.2000 \times 10^{-6}$ \\
\hline$K_{R}(1 / m i n$ & $7.6466 \times 10^{-12}$ & $8.4207 \times 10^{-12}$ & $8.9293 \times 10^{-12}$ & $9.7630 \times 10^{-12}$ & $9.7630 \times 10^{-12}$ \\
\hline$\varepsilon_{p}(1 / m g)$ & $5.2310 \times 10^{6}$ & $9.5003 \times 10^{6}$ & $8.6587 \times 10^{5}$ & $1.4339 \times 10^{5}$ & $1.2291 \times 10^{5}$ \\
\hline$\tau_{1 / 2}(\mathrm{~min})$ & 9.9687 & 4.9843 & 66.4581 & 284.8208 & 332.2909 \\
\hline$N_{0}(\mathrm{mg} / l)$ & 5000.0000 & 16666.6700 & 5000.0000 & 3333.3300 & 3333.3300 \\
\hline$\left(N_{P}\right)_{0}$ & $3.0110 \times 10^{24}$ & $1.0036 \times 10^{25}$ & $3.0110 \times 10^{24}$ & $2.0073 \times 10^{24}$ & $2.0073 \times 10^{24}$ \\
\hline
\end{tabular}

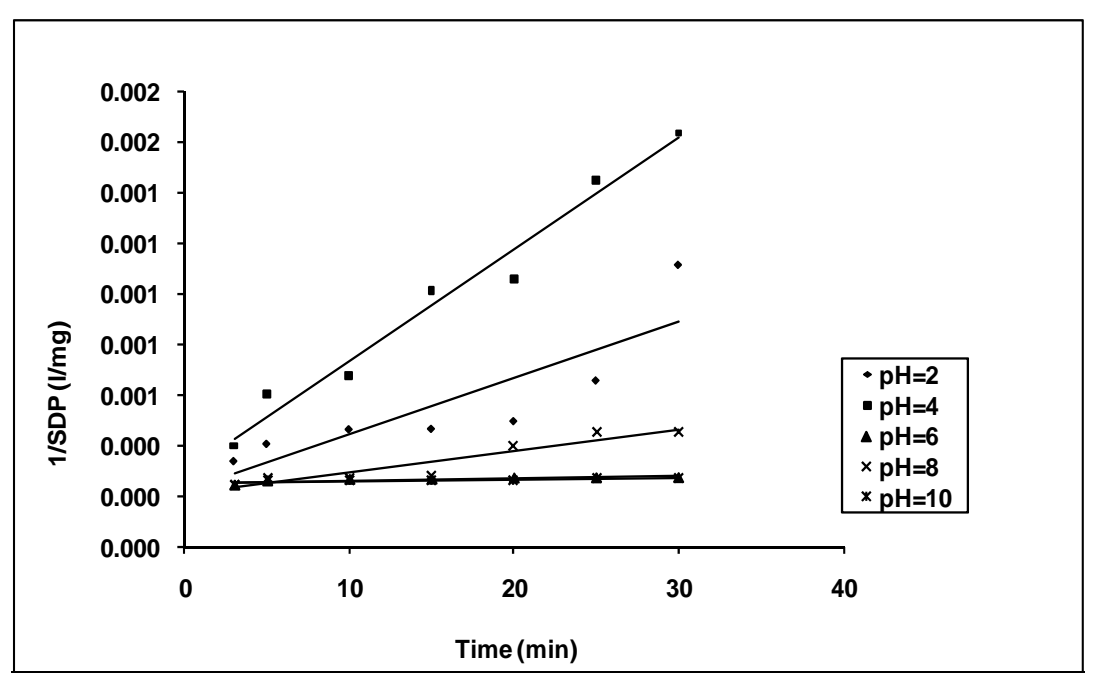

Figure 1. Representative plot of $1 / \mathrm{SDP}$ as function of time for $100 \mathrm{mg} / \mathrm{l}$



Figure 2. Particle distribution as a function of time at minimum half life of $2.4921 \mathrm{~min}$ 


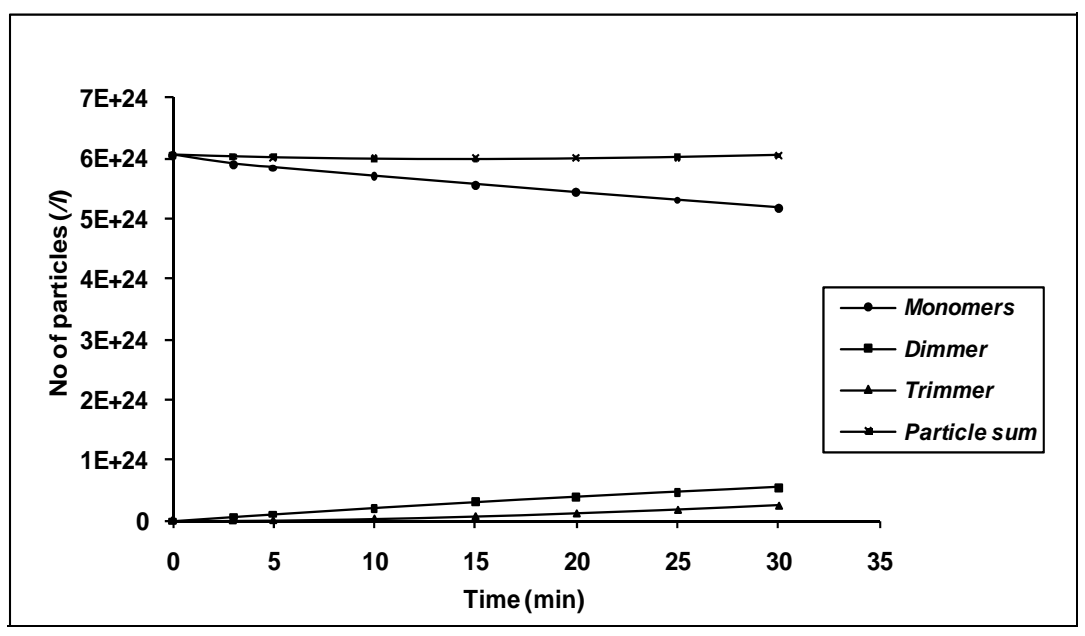

Figure 3. Particle distribution as a function of time at maximum half life of $398.7491 \mathrm{~min}$

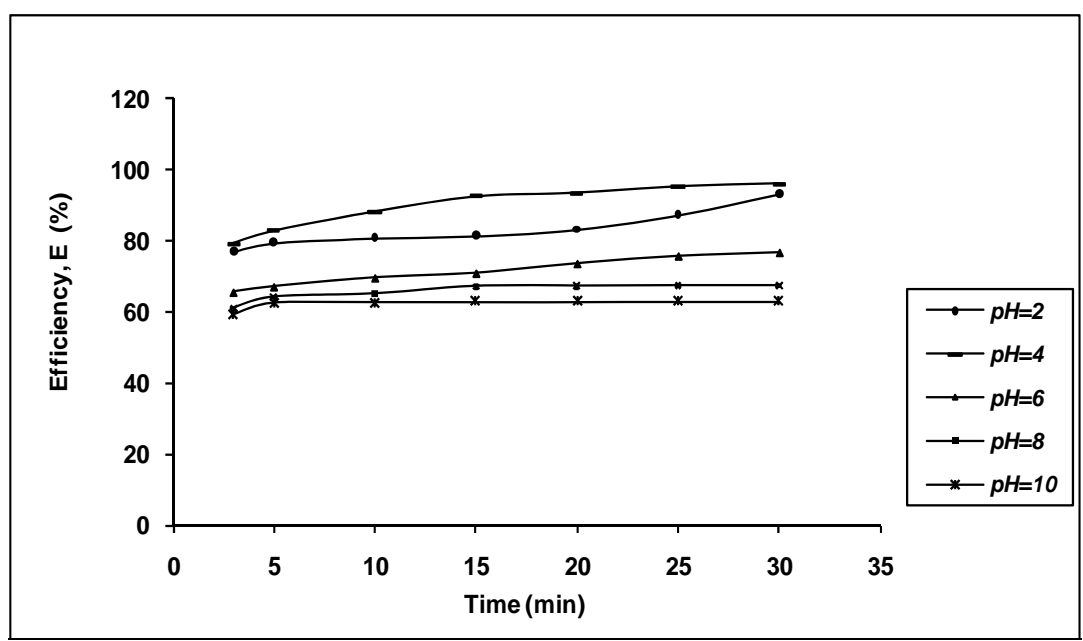

Figure 4. Efficiency as a function of time for BRE at $100 \mathrm{mg} / \mathrm{l} \mathrm{ABC}$

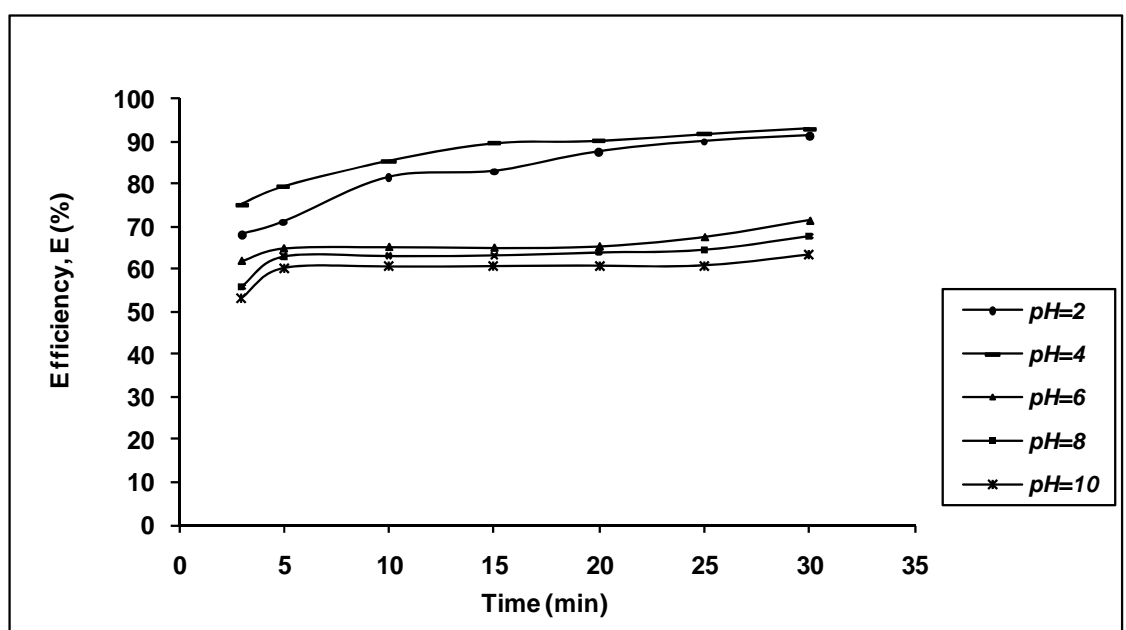

Figure 5. Efficiency as a function of time for BRE at $200 \mathrm{mg} / \mathrm{l} \mathrm{ABC}$ 


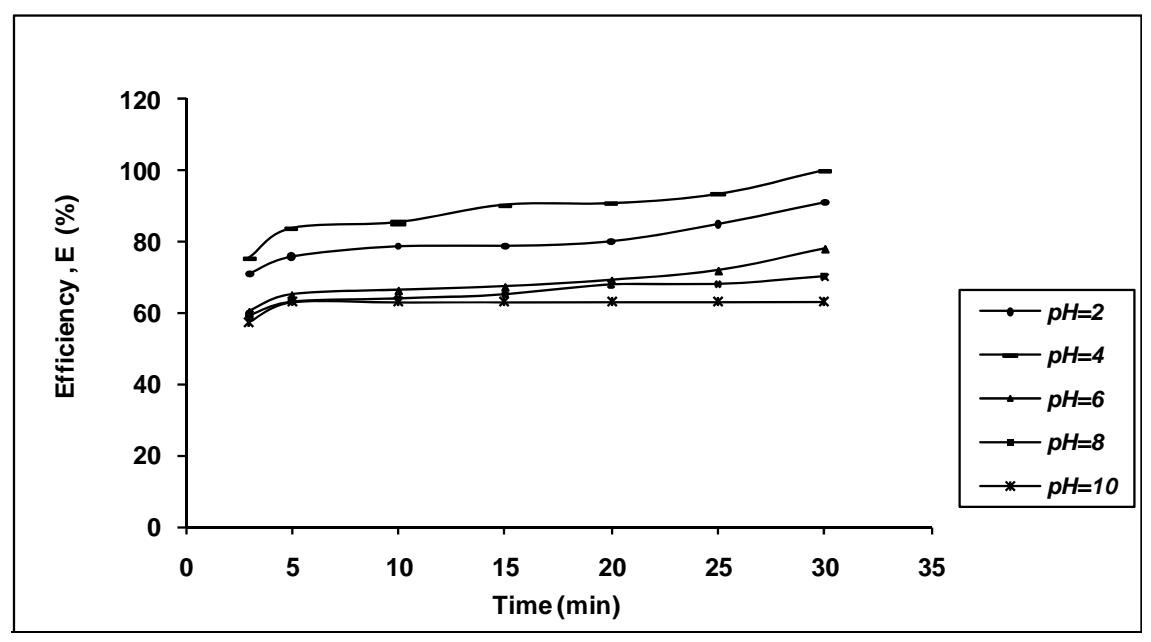

Figure 6. Efficiency as a function of time for BRE at $300 \mathrm{mg} / \mathrm{l} \mathrm{ABC}$

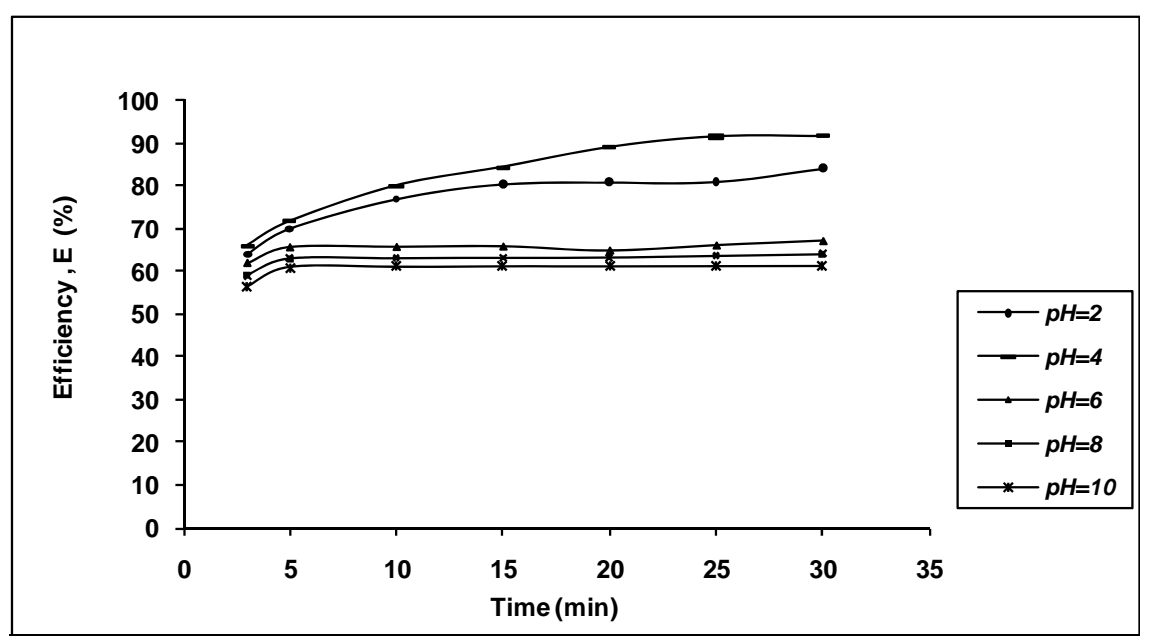

Figure 7. Efficiency as a function of time for BRE at $400 \mathrm{mg} / \mathrm{ABC}$

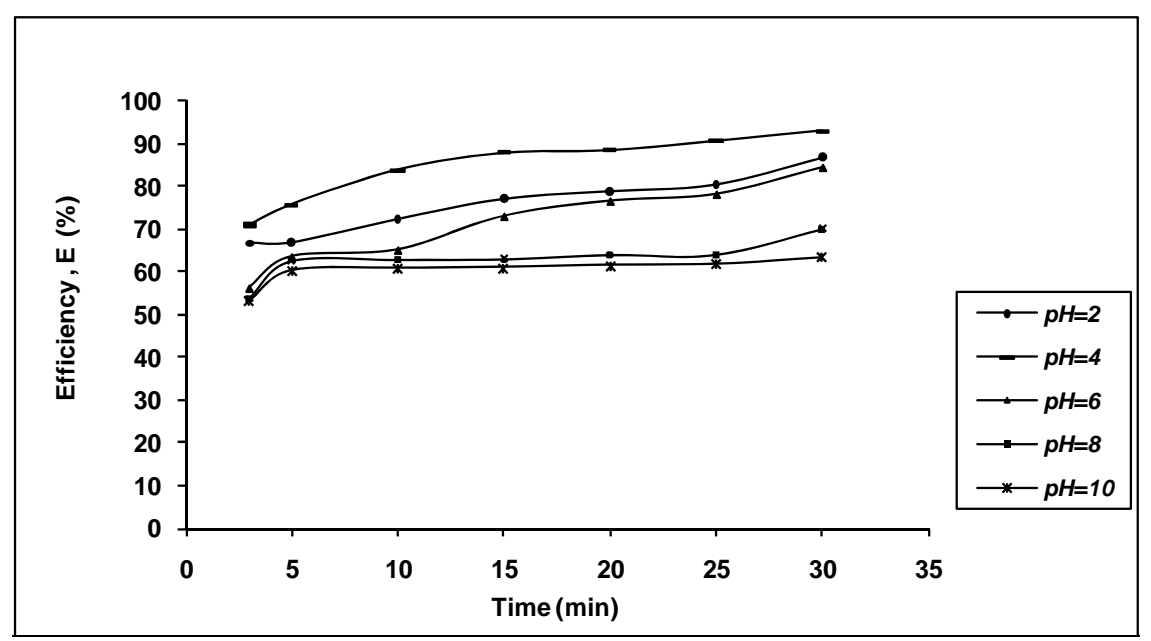

Figure 8. Efficiency as a function of time for BRE at $500 \mathrm{mg} / \mathrm{l} \mathrm{ABC}$ 




Figure 9. Comparative performance between $\mathrm{ABC}$ and Alum at $30 \mathrm{mins}$ and $100 \mathrm{mg} / \mathrm{l}$ doasge 